\title{
Genusregimer och kvinnors identiteter som industriarbetare Röster från Volvofabriker i
Sverige, Mexiko och Sydafrika
}

Diana Mulinari, Nora Räthzel \& Aina Tollefsen

\section{Inledning}

Omfattande och viktig forskning har gjorts om så kallade exportproduktionszoner (EPZ) i länder i det globala syd där vinster genereras under våldsamma former av överexploatering (Fernandez Kelly 1984; Salzinger 2003; Tornhill 2011). Vår forskning om anställdas arbetsliv i det transnationella bolaget Volvo är ett försök att förstå den globaliserande kapitalismens "normalitet", till skillnad från den situation som råder i sammanhang av våldsam överexploatering.

Med "normalitet" (se vidare nedan) menar vi en situation där industriell produktion "fungerar som den ska" i ett kapitalistiskt system. "Normala" produktionsförhållanden bör innefatta att de anställda får en lön som går att leva på (a living wage), att de skyddas mot hälso- och säkerhetsrisker och att deras företrädare accepteras. Vad det konkret innebär varierar naturligtvis (vad som är en lön som går att leva på skiljer sig mellan länder och tidsepoker), men principen är densamma. Vi menar att en analys av kapitalismen i en situation där den antas fungera "normalt", enligt sina egna regler, kan vidga vårt perspektiv på dess inneboende motsättningar. 
Vi ville analysera om, och i så fall hur, ett transnationellt företag som gjort sig känt för att betala rättvisa löner och tillämpa jämställdhetsprinciper i nord upprätthåller denna princip i det globala syd. Är det möjligt för ett företag i en globaliserad ekonomi att undvika att tillämpa överexploatering? Volvokoncernen har historiskt i Sverige och internationellt uppfattats som en bra arbetsgivare, och den var en av de första som ersatte löpande bandet med arbete i grupp för att ge arbetstagarna större flexibilitet och kontroll över arbetsplatsen (Berggren 1992; Wallace 2007).

Vi har studerat Volvos fabriker i Umeå, Tultitlán (Mexiko), Durban (Sydafrika) och Bengaluru (Indien), men vi behandlar i det här kapitlet inte fabriken i Indien, där endast en kvinna arbetade i produktionen. Syftet var att analysera Volvoanställdas erfarenheter och försöka fånga hur erfarenheterna formades av företagets transnationella profil och det nationella och sociopolitiska sammanhanget. Mer specifikt undersökte vi vilken roll genus spelade som symbol, identitet (Hall 1996) och social relation i konstruktionen av Volvoarbetare i olika samhällen.

Vi utgår från Raewyn Connells definition av genusregim (Connell 2005, 6; vår översättning): "Med en institutions 'genusregim' menar vi mönstret av könsrelationer i institutionen, särskilt det fortlöpande mönster som utgör det strukturella sammanhanget för specifika relationer och individuella praktiker." En genusregim innefattar enligt Connell arbetsfördelning och maktförhållanden mellan könen, känslor och mänskliga relationer liksom identitet, språk och symbolism. Vårt främsta fokus var de ojämlika arbetsrelationerna mellan manliga och kvinnliga anställda och hur de formades av olika genusregimer. Vi undersökte de former av ojämlikhet som skapades utifrån de skilda positioner som manliga och kvinnliga arbetare intog på de arbetsplatser vi studerade. Vad finns det för likheter och skillnader mellan länder i det globala syd och nord vad beträffar kvinnors erfarenheter som industriarbetare i en manligt dominerad industri?

Under de senaste decennierna har feministiska forskare undersökt hur genus artikuleras som social relation, som identitet och som en appropiering av nyliberala ideologier och praktiker. Å ena sidan har forskarna identifierat den roll kvinnor ofta intar inom osäkra, prekära arbeten. Å andra sidan har både transnationella företag och statliga 
aktörer associerat det kvinnliga med flexibilitet och förmåga att anpassa sig till nya tider, i en diskurs där det manliga (och fackliga) ofta konstrueras som stelt och fixerat.

Enligt ILO (International Labour Office 2018) är kvinnors ökade förvärvsarbete en av de viktigaste och största förändringarna i den globala arbetskraftens struktur. Samtidigt har kvinnors mer omfattande integration i betalt arbete sammanfallit med en ökad prekarisering av arbetet eller, som Guy Standing uttryckt det, en "feminisering" (Standing 1989). Kvinnors inträde på arbetsmarknaden har präglats av villkor som är typiska för kvinnors arbete: deltid (tidsflexibilitet) och låga löner. Samtidigt har feministiska forskare visat att trots att kvinnor främst anställts i prekära arbeten har de utvecklat nya identiteter som arbetare (Chant 2014; Darkwah 2007; Eraydin \& Erendil 1999; Ong 2006). Vi tar avstamp i det när vi diskuterar kvinnliga industriarbetares erfarenheter i det globala syd och nord. En viktig skillnad från de ovan citerade studierna är att de kvinnor vi intervjuade inte hade "feminiserade" arbeten utan tvärtom var industriarbetare och utförde vad som betraktas som "manligt arbete", och de var fast anställda på heltid i enlighet med den traditionella fordistiska modellen. Som vi kommer att förklara nedan så var detta en del av vårt försök att undersöka "normaliteten" i de kapitalistiska produktionsförhållandena.

\section{Teoretiska reflektioner}

\section{Kapitalismens normalitet}

Vi härleder begreppet "normalitet" från Marx analys av kapitalismen. I sitt förord till första utgåvan av Kapitalet. Bok 1 förklarade han sin metod genom att jämföra den med fysikerns sätt att arbeta (1867/1998):

Fysikern observerar naturprocesserna, antingen där de framträder i den mest pregnanta formen och minst grumlade av störande inflytelser, eller också gör han, om möjligt, experiment under sådana betingelser, att processens renhet garanteras. I detta verk är det min uppgift att utforska det kapitalistiska produktionssättet och de däremot svarande produktions- och utbytesförhållandena. 
Marx preciserar kapitalismens normalitet och funktionssätt under arbetets gång och inleder med penningens förvandling till kapital (1867/1998, 239): "Penningens förvandling till kapital måste förklaras utifrån varubytets inneboende lagar, så att utbyte av lika stora värden gäller som utgångspunkt.” Att analysera kapitalismen under antagandet att den fungerar helt enligt sina egna lagar och regleringar (även om så aldrig är fallet) var viktigt för Marx. Han såg det som en förutsättning för att kunna granska systemet kritiskt och synliggöra dess centrala strukturer. Om man bara analyserar avvikelser från det kapitalistiska produktionssättets egna lagar kan man få uppfattningen att det går att lösa dess problem genom att återgå till "normaliteten". Om däremot problemen finns när systemet fungerar "normalt" visar det att systemet i sig är ett problem. Om till exempel "feminiseringen" av arbetet uppfattas som ett problem skulle en lösning kunna vara att skapa stabila, långsiktiga heltidsarbeten.

Även vår användning av begreppet "överexploatering" utgår från Marx, och vi har inspirerats av en rad latinamerikanska forskare som har identifierat att arbetsintensivt produktivt arbete ofta placeras i syd till låga löner. Under kapitalismen är exploatering en normalitet och en förutsättning. Arbetare ersätts till bytesvärdet för arbetskraften, det vill säga de medel som krävs för att producera den (mat, kläder, bostäder, utbildning, säkerhet, hälsa etcetera), samtidigt som de på arbetet producerar mer värde än så. Under "normal" exploatering får arbetarna en lön som ersätter dem för bytesvärdet. Överexploatering innebär att lönen inte täcker bytesvärdet.

Det transnationella företaget Volvo $\mathrm{AB}$ är på många sätt emblematiskt för fordismen. Gramsci (1971) och andra har betraktat fordismen som en form av massproduktion och masskonsumtion som byggde på rationalitet och effektivitet och som syftade till att organisera inte bara arbetsprocessen utan också arbetarnas liv utanför arbetet, inklusive fritidsaktiviteter och relationerna mellan könen. Fordismen utvecklades under industrialismens glansperiod, och arbetarnas maskinella underordning i fabrikerna ackompanjerades i idealfallet av säkra arbetsförhållanden och relativt höga löner för arbetskraften. Under den ekonomiska nyliberalismen har Volvo emellertid infört ett postfordistiskt 
produktionssystem baserat på lean production och takt time (se Räthzel, Mulinari \& Tollefsen 2014).

Många feministiska forskare har analyserat klass, genus och etnicitet under den globala kapitalismen (Enloe 2004; Federici 2014; Gibson-Graham 2006; Mohanty 1997, 2003; Nagar m.fl. 2002), inklusive de sätt på vilka intersektionella sociala relationer positionerar kategorin kvinnor i olika kombinationer av dominans och exploatering (Ferguson 2016; Glenn 1992; Grabham m.fl. 2009; Hennessy 2000).

Vi vill bidra till det forskningsfält som undersöker länkar mellan finanskapitalets globala hegemoni, genusarbetsdelningens förändringar som en effekt av nyliberala ekonomiska anpassningar och den nyliberalistiska ideologi som legitimerar dessa processer.

\section{Genusregimer}

När vi använder begreppet "genusregim" i vår analys anknyter vi inte bara till Raewyn Connells definition som vi återgav i inledningen, utan även till hennes tidigare tillämpningar av begreppet. I boken $\mathrm{Om}$ genus (2002) använde hon det för att fånga heterogenitet och specificitet i organisationer och institutioner (familj, skola, arbetsplatser) inom ramen för en samhällelig genusordning. I sin analys av staten i en artikel 1990 förklarade hon begreppet så här (1990, 509): "Kvinnor och män tenderar att inta specifika positioner inom staten, och arbeta på sätt som struktureras av institutionella genusrelationer, vilka kan analyseras genom en strukturell kartläggning." De positioner som kategorierna kvinnor och män intar i en institution är beroende av, men inte en direkt spegling av, genusordningen i samhället. En genusregim skapas av alla medlemmar i en institution eller organisation, inte bara av dem som innehar ledningsfunktioner. Män och kvinnor för med sig socialt konstruerade bilder av genus till arbetsplatsen och förhandlar sina positioner inom givna maktrelationer både i samhället och på arbetet. Vi frågade oss vilka genusregimer som utvecklades på de olika Volvofabrikerna mot bakgrund av deras sociohistoriska sammanhang och de ledningsstrategier som tillämpades. 


\section{Betydelsen av plats}

I och med att vi undersökte fabriker som tillhörde samma transnationella företag i olika länder var Doreen Masseys (2005) insikt att "lokal/ global" inte är en dikotomi speciellt viktig för oss. Faktum är att samband mellan skilda nivåer och skalor (det lokala, det nationella, det globala) blev uppenbara när vi talade med arbetarna. De förklarade sina livssituationer i termer av att tillhöra ett transnationellt bolag och samtidigt hade de erfarenheter av hur detta påverkade deras ställning bland vänner och släktingar. De gav uttryck för vad företagets närvaro innebar för det egna landet, för dem själva och för den plats där de bodde. De kände samhörighet med Volvoanställda över hela världen på olika och ibland ambivalenta vis. De upplevde definitivt en global platskänsla (a global sense of place) (Massey 1994) som innebär att den egna platsen konstitueras av både nära och fjärran relationer. Det visar att vi måste ifrågasätta uppfattningar om att identiteter är bundna till nationella stereotyper eller "nationella arbetskulturer", samtidigt som lokala platser också fordrar att globala företag anpassar sig. Vi uppmärksammade hur nationella, lokala och globaliserande arbetskulturer skar igenom tider och platser. Hur dessa processer formade och formades av kvinnors subjektiviteter står i centrum för denna text.

\section{Genusregimer, plats och kvinnors subjektiviteter}

Den feministiska kulturteoretikern Angela McRobbie (2009) menar att nyliberala ideologier har appropierat diskursen om kvinnors befrielse och jämlikhet genom att omstöpa den till en diskurs om individualistiskt "entreprenörskap". Kvinnor, särskilt unga kvinnor, blir till ideala entreprenörer. Kvinnorna i vår studie hade vanliga anställningar, men de identifierade sig med arbetet på ett sätt som påminde om detta resonemang - dock utan att se sig själva som chefer över arbetet. Volvos företagskultur uppmanade till individuella prestationer och bejakade anställdas individuella ansvar och förmåga att vidareutveckla produktionen. För kvinnorna var det en utmaning de gärna antog, i synnerhet som det innebar en framgång för dem att kunna utföra det som ansågs vara "mansjobb" och de ville visa att de var värda det. 
Liksom andra feministiska forskare vill vi utveckla en förståelse för kvinnors identiteter som identifierar strukturella sociala relationer såväl som den mänskliga förmågan att överträffa, utmana och till och med förändra dem. Den feministiska politiska filosofen Lois McNay (200o) konstaterar att en omformulering av agentskapets roll inom feministisk teori bör undvika både determinism och voluntarism. Feministisk forskning har på senare tid analyserat hur genus och identitet förbinder språk, kropp och makt, och McNay framhåller behovet av att också förstå handlingar och sociala förändringar på den vardagliga nivån. Det är på den nivån vår forskning rör sig. Vi visar att "erkännande" och "förkroppsligad erfarenhet" är grundläggande för hur kvinnor ser på sig själva och sin ställning på arbetet. Liksom McNay menar vi att en intersektionell analys som syftar till att förstå subjektivitet och kvinnors agentskap behöver engagera sig i en bredare läsning av könsrelationer, utöver fokuset på sexualitet och femininitet. Kvinnliga industriarbetare utmanar uppfattningar om både vad en kvinna är och vad en industriarbetare är. Vilka former för genuskodad kvinnlighet utvecklas när kvinnor överskrider de traditionella formerna för arbetsdelning mellan könen på arbetsplatsen? Hur påverkas relationerna mellan de anställda av det faktum att kvinnor är närvarande som industriarbetare i fabrikerna?

\section{Om metodologi och metod}

Arbetstagarnas berättelser om sina erfarenheter av att vara anställda i ett och samma transnationella bolag hjälper oss att förstå globala processer. Erfarenheterna filtreras emellertid genom berättarens syn på världen och under den process då den intervjuade och intervjuaren gemensamt sammanfogar erfarenheterna. Vi som författare gör dessutom en extra filtrering när vi väljer vilka delar av berättelserna vi ska förmedla vidare och hur. Vi tillämpade den tredelade strategi som sociologen Dorothy Smith (2005) argumenterar för: a) vi utgår ifrån Volvoarbetarnas berättelser om sina arbetserfarenheter, b) vi identifierar några av de institutionella processer som format dessa erfarenheter och c) vi undersöker dessa institutionella processer för att analysera hur de fungerar som sammanhang för erfarenheterna. 
Metodologiskt är vi inspirerade av feministisk institutionell etnografi (Smith 2005) och Burawoys (1998) så kallade utökade fallstudiemetod (extended case method). Både institutionell etnografi och den utökade fallstudiemetoden bygger på en marxistisk tradition där tonvikten ligger på att förstå handlande utifrån människors egna berättelser men också inom ramen för den historiska sociopolitiska kontexten, vilken öppnar för vissa subjektspositioner och stänger andra.

Vi intervjuade 97 Volvoanställda (9o arbetare och 7 chefer) i Mexiko, Sydafrika, Indien och Sverige. I Mexiko valde fabriksledningen ut personer till våra intervjuer, enligt våra kriterier: variation med avseende på kön, ålder, ställning på arbetsplatsen och anställningstid på fabriken. Utifrån samma kriterier valde fackföreningen i Umeå ut de arbetstagare vi intervjuade där (ledningen avböjde att medverka). I Sydafrika gjorde vi själva urvalet av arbetare, medan det i Indien var fackföreningen som hjälpte oss att hitta arbetstagare.

Urvalet är inte statistiskt representativt, men sammansatt för att möjliggöra samtal med arbetare från olika sociala och arbetsspecifika positioner i varje land. I alla länder utom Mexiko fick vi banda intervjuerna. I Mexiko kunde vi likafullt fånga upp ett antal formuleringar och meningar som vi citerar i kapitlet.

Vi följde en gemensam intervjuguide, transkriberade intervjuerna och använde programmet Max QDA för att koda materialet. I huvudsak genomförde vi intervjuerna på tu man hand, men att vi alla tre var närvarande på de olika arbetsplatserna under forskningsprocessen möjliggjorde ett produktivt vetenskapligt samtal där vi kritiskt kunde granska olika tolkningar av det empiriska materialet. Vi reste gemensamt till alla Volvofabriker och samtalade med varandra efter varje arbetsplatsbesök. På så sätt kunde vi analysera våra första intryck och våra olika tolkningar konfronterades med varandra. Givet de skilda geografiska lokaliseringarna blev vi överraskade av de förhållandevis stora likheterna i de anställdas erfarenheter och de sätt de berättade om dem i de olika sociala, politiska och ekonomiska sammanhangen.

Under läsningen av intervjuerna och fältanteckningarna kodade vi uttalanden som anknöt till vår centrala forskningsfråga om hur arbetet formar sociala relationer inom och utanför arbetsplatsen samt människors identiteter som anställda i ett transnationellt företag. Det innebar 
att vi uppmärksammade hur de intervjuade konstruerade sig själva och hur de konstruerades av ledningen. Berättelserna berörde ämnen som arbetsvillkor, horisontella och vertikala samarbetsformer, könsspecifika relationer på och utanför arbetsplatsen, familjerelationer, resor mellan hemmet och arbetet samt migrationsprocesser.

Förutom intervjuerna bestod vårt empiriska material av observationer, fältanteckningar och företagets egna dokument.

I det här kapitlet analyserar vi utsagor om hur könsrelationer erfors och skapades horisontellt mellan män och kvinnor på arbetsplatsen såväl som vertikalt genom ledningens praktiker och policyer. Vi gjorde ytterligare läsningar utifrån vissa grupper av arbetare (kvinnor, unga män och äldre män) och utifrån olika teman.

I vår monografi (Räthzel, Mulinari \& Tollefsen 2014) och i artiklar (Mulinari \& Räthzel 2009; Mulinari, Räthzel \& Tollefsen 2011; Räthzel, Mulinari, Tollefsen m.fl. 2008) har vi analyserat andra relationer på arbetet vid Volvofabrikerna i de fyra länderna.

\section{Tre fabriker, tre genusregimer}

\section{En kvinnas dag}

Jag vaknar klockan 4.30, sätter på värmen, gör i ordning frukost och barnens lunch. Jag ringer barnen när jag sitter på bussen så att de stiger upp och går till skolan. På eftermiddagen när jag kommer från jobbet måste jag hjälpa dem med läxorna, gå igenom vad de inte förstått $\mathrm{i}$ skolan [...]. Min dag slutar klockan 23.30. Jag går och lägger mig oo.30. Jag sover mellan tre och en halv och fyra timmar per natt. (Olga, Tultitlán, Mexiko)

Det är det största problemet. Jag måste gå upp väldigt tidigt. Det är inget problem med den äldre, hon klarar sig själv. Men den lille: Jag måste göra mig i ordning och klä på honom medan jag förbereder deras lunchpaket. Sedan måste han in i mitt rum, eftersom jag måste låsa rummet. Det är det som är det svåra. Han måste vänta där påklädd i mer än en timme. Vi måste vara på jobbet före sju. Man blir trött. Jag blir trött efter teet, efter två. Nästa vecka kommer vi att jobba övertid, 
vi pratade om det. Det är svårt att arbeta från sju till sju. Men vi ska försöka. (Lesedi, Durban, Sydafrika)

När vi kommer hem från jobbet klockan 16.30 går vi genom hallen och lämnar våra jobbväskor och sen går vi ut genom trädgårdsdörren och börjar prata. Och sen när vi klarat av det viktigaste, då går jag in och fixar maten. (Maya, Umeå, Sverige)

Olga i Tultitlán, Lesedi i Durban och Maya i Umeå är industriarbetare på mansdominerade arbetsplatser. De är kodade som kvinnor inom dessa industriella relationer och lever i samhällen med genusarbetsdelning. Var och en av dem har två arbetsplatser: fabriken och hemmet. Deras sätt att prata om sin arbetsdag belyser skillnaderna mellan de tre arbetsplatserna och genusregimerna. Olga och Lesedi har arbetsdagar som omfattar långa och tröttsamma transporter i form av två timmars resa mellan arbetsplatsen och hemmet. I en annan del av intervjun talar Olga om telefonen som ett grundläggande verktyg för att kunna förena sina dubbla roller som mamma och arbetare, vilket illustrerar spänningen mellan privatliv och arbetsliv. Lesedis kamp för att hantera obekväma arbetstider åskådliggör det existentiella behovet av att ha ett avlönat arbete i ett land med ökande arbetslöshet där en lön måste räcka till en hel familj. Olgas arbetsförhållanden förbättras av bussen som den mexikanska fabriken ställer till förfogande, medan Lesedi måste ta dyra privata minibussar till jobbet. Frånvaron av företagstransport förstärker ras- och klasshierarkier i den segregerade staden Durban. En av de kvinnliga arbetare vi pratade med i Durban reste nästan elva mil om dagen för att komma till fabriken. Klasshierarkierna överskuggade rashierarkierna när det gällde bostäder; vi kunde konstatera att personer i Volvofabrikens ledning, oavsett om de definierades som vita, svarta eller indiska, bodde precis i närheten av fabriken.

I berättelserna om problemen med resorna till jobbet fann vi också könsbestämda sätt att föreställa sig möjliga lösningar. Nästan alla unga svarta män i den sydafrikanska fabriken såg det som en prioriterad lösning att köpa bil, medan kvinnorna önskade en bostad närmare fabriken. Olga och Lesedi ville ha lösningar som primärt utgick ifrån deras roller som mödrar, vilket belyste en källa till konflikt mellan Volvo och dess 
anställda kvinnor. Mayas historia var annorlunda. Hennes beskrivning av dagen börjar med att hon och hennes man kommer från jobbet tillsammans och kopplar av i trädgården. Många arbetare vi pratade med i Umeå hade egna hus i närheten av fabriken, flera med stora trädgårdar. Den svenska välfärdsstaten erbjuder offentlig barnomsorg, vilket har gjort det möjligt för Maya att under sina tjugo år i företaget uppfostra två barn medan hon kombinerat familj och arbete. Men trots jämställdhetspolitiken i Sverige har Maya, liksom de flesta kvinnor i Sverige, huvudansvaret för hushållsarbetet (för mer om kategorin kvinnors roll i omsorgsarbete, se Benería 2008; Brenner 2000; Farris \& Rottenberg 2017; Nilsen m.fl. 2017; SOU 2004). På Volvo i Umeå arbetar ofta makar och flera familjemedlemmar, vilket skapar ett särskilt förhållande mellan könen utanför och i fabriken. Spänningarna mellan arbete och familj finns i det "vi" som Maya hänvisar till när hon kommer hem med sin partner, och det "jag" som går in och lagar mat, ett gängse kvinnojobb.

Två gemensamma förhållanden överskuggar nord-syd-klyftan: kvinnorna i alla tre fabrikerna fortsatte att vara ansvariga för det reproduktiva arbetet och i alla tre fabrikerna betraktades de som malplacerade, eller out of place.

\section{Mexiko: Nyliberal ekonomisk utveckling och genusrelationer i förändring}

Skiftet från en nationell utvecklingsstrategi baserad på importsubstitution till en nyliberal modell inriktad på exportdriven tillväxt i Mexiko under 1980-talet innebar en djupgående ekonomisk och social omstrukturering i landet, med förändrade genus- och arbetsrelationer som följd (Cortés 2000; Gutierrez Arriola 2006). Under de följande decennierna skedde en intensifiering av kvinnors lönearbete, i omsorgs- och servicearbeten, i privatiserad tidigare nationell industri och i maquiladoras (Benería 1992; de la Rocha 2001; de la Garza 2006). Maquiladoras är transnationella företag i Latinamerika, inte minst i Mexiko och Nicaragua, som verkar under ett särskilt avtal inom ramen för North American Free Trade Agreement (NAFTA) och kännetecknas av låga löner och osäker arbetsmiljö (se Funari \& de la Torre 2006). Hushållet som enhet har blivit allt viktigare som buffert vid ekonomisk kris, med tanke på 
att alla familjemedlemmar måste bidra till försörjningen (Latapi \& de la Rocha 2009). Samtidigt arbetar endast 17 procent av de kvinnliga förvärvsarbetarna inom industrin (Arciniega 2012; Vanguardia 2017).

Ett huvudtema i kvinnornas berättelser var den centrala betydelse kvinnors betalda arbete har för de mexikanska hushållens och samhällets överlevnad (de la Rocha 2015). Vi pratade med åtta kvinnor, varav tre hade män som migrerat för att arbeta i USA.

Min man har varit i USA i ett år. Han har jobbat på olika ställen, han skulle komma tillbaka i december men det kommer inte att gå. [...] Han har ettårskontrakt nu. Man måste ha tålamod. Situationen är svår överallt. Den ekonomiska situationen i Mexiko är instabil. Man måste göra det för sina barn. Man måste uppoffra sig för sina barn. I USA är jobben mindre stabila än här. Han är tvungen att jobba i en fabrik med väldigt låga löner, han skickar varje öre han tjänar. Men det har inte gett oss några fördelar. (Gaby)

Gaby beskriver den könsbestämda arbetsmigrationen utifrån sina erfarenheter som en av dem som stannar kvar. Hon betonar betydelsen av "uppoffring", ett begrepp som kvinnorna använde både i Mexiko och i Sydafrika. Att uppoffra sig var en förutsättning för att uthärda orättvisa arbetsvillkor, uppoffringen var nödvändig för barnens och deras framtids skull. Men vi förstod att kvinnornas identifikation med det reproduktiva arbetet var tveeggad, vilket annan forskning också visat (Lagarde de los Ríos 2011). Identifikationen kunde få kvinnorna att acceptera en högre grad av exploatering, men den kunde även leda till en medvetenhet om att lönearbetet stod i konflikt med deras roll som mödrar (Solis de Alba 1990).

För de flesta kvinnor är "hemmafru" (ama de casa, bokstavligen "husets själ") en identitet från det förflutna när arbetarklassens män kunde tjäna tillräckligt för att försörja en familj. Det framkom tydligt när kvinnorna beskrev sitt arbete. Oftare än männen betonade de hur stolta de var över att arbeta i produktionsprocessen, och över att kunna hantera arbetet bättre än sina manliga arbetskamrater. 
Han sa att "det här är perfekt”. Han var förvånad. Och jag förstod att jag kan utföra vilket arbetsmoment som helst. Jag har hört kommentarer om personer som tillverkat delar som sedan varit obrukbara. (Olivia)

Jag känner mig nöjd över att göra ett jobb som två personer gjorde tidigare, nu gör jag det helt ensam, jag hanterar det själv. Det ger mig tillfredsställelse, jag kan det här. Vi kvinnor slutför vad vi påbörjar. Vi är smidigare och snabbare. Som hemma. Kvinnor kommer hem, fixar det som måste göras och planerar för morgondagen. Vi har en rytm. Det har inte männen. (Elena)

I kvinnornas berättelser om sitt arbete i och utanför fabriken framkom att lönearbetet inte bara var ett sätt att tjäna pengar utan även ett sätt att utveckla ett nytt självförtroende och en ny identitet - en identitet som "kvinnor som kan", det vill säga kvinnor som kan göra ett jobb som definieras som ett mansjobb. Samtidigt beskrev de hushållsarbetet som något de snabbt och effektivt klarade av. Förändrade genusrelationer medförde förändringar i hur kvinnorna såg på sig själva, de uppskattade att hela tiden vidareutbilda sig, att utveckla självständighet genom att inse att de var kompetenta. Med de villkor de arbetade under hade detta självförtroende emellertid ett högt pris: en arbetsdag som sträckte sig från gryning till solnedgång och en konstant kamp för erkännande på arbetsplatsen:

De [de manliga arbetskamraterna] tror att vi är ute efter att ragga, men hur kan man vilja det när det enda man vill är att åka hem och sova? Man vill göra ett bra jobb, helt enkelt. Men de kommer att behöva förändra sitt synsätt eftersom vi visar dem vad vi är värda. (Inez)

En viktig skillnad blev emellertid uppenbar i samtalen om kvinnors avlönade arbete med manliga arbetare från olika generationer: ett generationsgap i mäns syn på kvinnors betalda arbete (tidigare påvisat i Gutmann 1996; Szasz \& Amuchástegui 2007). De flesta män i trettioårsåldern pratade på ett självklart sätt om sina fruars lönearbete, medan de över femtio uttryckte sin respekt för fruarna genom att beteckna dem som "goda administratörer" av männens inkomster. De menade att om kvinnor är "goda administratörer" och om män och kvinnor 
lever disciplinerat (ingen öl, ingen lyx) är det inte nödvändigt för (gifta) kvinnor att bli Volvoarbetare.

\section{Sydafrika: Svarta kvinnor i industriellt arbete - stolthet och vårdansvar}

Iris Bergers (1992) forskning om kvinnliga industriarbetare i Sydafrika fann inte bara samband mellan kön och ras och vissa ekonomiska branscher, utan visade också att kvinnor spelade en central roll i facklig organisering och i kampen mot apartheid. Vi träffade svarta kvinnliga industriarbetare som var helt utarbetade, samtidigt som de var stolta över att arbeta i produktionen och bygga lastbilar. De såg sig som överlevare och fighters, men i en situation med en frånvarande (nyliberal) stat (Darkwah 2007; Mosoetsa 2005) innebar de höga kraven som arbete och familj ställde på dem att livet blev svårt.

Jag har ett mycket bättre jobb nu. Mina småsyskon kan inte arbeta. Ibland är jag den enda som försörjer familjen. Det är min plikt. De försörjde mig tills jag var tjugotvå. Jag gör mitt bästa. Min mamma jobbar inte och min pappa är sjuk. Så jag måste ta hand om dem, de är min familj. [...] Jag är äldst. Och jag måste ge mina bröder en framtid. Efter det kanske jag får min chans. Jag ser på den minste som mitt eget barn. Han är min förste son. För en mor har den förste sonen högsta prioritet. Så min fästman förstår. Han ville gifta sig 2007 men då sa jag att vi måste vänta tills jag har gjort allt för mina föräldrar och mina bröder. (Cebile)

Cebile beskriver spänningen mellan sina egna önskningar och de många kraven. Hon slits mellan en önskan att ta hand om sin familj och en önskan att skapa en egen familj. Hon försöker lösa spänningen genom att behandla sin lillebror som sin son. Cebile accepterar sin roll som familjeförsörjare och ser det som en plikt, men är ledsen över att inte kunna bilda en egen familj. I Sydafrika är arbetslösheten bland svarta kvinnor 34,2 procent, och bland svarta kvinnor i åldern 15-34 år så hög som 40,0 procent, samtidigt som arbetslösheten generellt ligger 
på 27,7 procent (Stats.sa 2018). Cebiles roll som hushållets försörjare är ett undantag och vi uppfattade att hon kände stolthet över att kunna inneha den positionen i sin familj.

För våra intervjuade var "hushållet" ett brett begrepp. Några bodde tillsammans med eller hade vuxit upp med mostrar och mor- eller farföräldrar och tog hand om syskon och föräldrar och även mer avlägsna släktingar. Utan välfärdsordningar blir i många fall de unga familjemedlemmarna det enda skyddsnätet, speciellt de unga som haft möjlighet att få en anställning. Diskursen om en rättvis moralisk ekonomi med omfattande skyldigheter och rättigheter utgör en ideologisk grund för människors handlande. I de sydafrikanska berättelserna var begreppet "ömsesidighet" starkt närvarande: föräldrarna hade offrat sina liv och resurser för att ta hand om dem, nu var det deras tur, deras "plikt", som Cebile uttryckte det. Hushållens moraliska ekonomi har historiskt reglerats av värderingar och normer som definierar rättigheter, skyldigheter och former av ömsesidigt utbyte.

Bördan att ta hand om en storfamilj kan vila på unga människors axlar. Det gör att människor kan överleva, men för vissa familjemedlemmar sker det på bekostnad av den egna framtiden. Berättelserna synliggör erfarenheter av att växa upp i hushållsekonomier baserade på ömsesidigt beroende och solidaritet. Enligt den feministiska forskaren Obioma Nnaemeka är samarbete, förhandlingar och kompromisser viktiga inslag i det afrikanska könsuppdelade livet (Nnaemeka 1998; Tshoaedi 2012). I samband med den ekonomiska omstruktureringen och nya osäkra relationer på arbetsmarknaden bryts de mönster som reglerat hushållsekonomierna. Det skapar en särskild stress för familjemedlemmar som förväntas fördela resurser till olika medlemmar av hushållet och prioritera andra än sig själv (Gibson \& Rosenkrantz Lindegaard 2003).

Intervjuerna förmedlade en bild av den äldre generationen som utsliten, sjuk eller oförmögen att hitta ett arbete. De vi intervjuade uttryckte en tilltro till att de tack vare sina anställningar äntligen skulle kunna ta hand om sina familjer. Dock visade det sig att deras jobb inte var så säkra och inte heller tillräckligt välbetalda för att försörja familjerna. När vi återvände till fabriken i Durban två år senare fick vi veta att majoriteten av de arbetare vi intervjuat hade blivit avskedade efter att ha strejkat 
för högre löner. Vi undrade vad det hade blivit av dem, deras syskon, föräldrar och syskonbarn. Vardagen för de unga arbetarna genomsyrades av ett omfattande ekonomiskt och känslomässigt ansvar för andra.

Trots att många kvinnliga arbetare, och även flera av de unga manliga anställda, tyngdes av bördan av att försörja andra familjemedlemmar och samtidigt utföra ett krävande jobb går det inte att reducera deras subjektiviteter till denna aspekt. Varken de mexikanska eller de sydafrikanska kvinnorna passar in i bilden av att vara kuvad under den dubbla bördan av lönearbete och ansvar för hushållet.

Jag har bra hand med lastbilarna. När jag är med mina vänner och en Volvolastbil passerar kan jag säga: "Hallå, jag har byggt den där." Och då säger de: "Kvinnor kan inte göra sånt." [...] Du vet hur killar är, när jag berättade att jag sökte jobb på Volvo sa de: ”Nej du kan inte, det är för killar.” Varför säger de det, att jag inte kan göra ett mansjobb? Kanske inte. Men jag försöker. Och när det ordnades en fest och togs bilder på fabriken var det jag som fotades och byggde lastbilen. Vi är kvinnor och vi kan göra mäns jobb. (Emana)

Emana, en ung zulukvinna, beskrev hur kulturella produkter och teknologi är könade. När hon säger "du vet hur killar är" bygger hon en bro mellan den unga sydafrikanska arbetaren och den medelålders intervjuaren med bakgrund i Sverige och Sydamerika. Oavsett klass och nationell bakgrund finns det något gemensamt: vetskapen om genusskillnader och ojämlika könsrelationer. Emana utmanar mäns auktoritet och motstånd mot hennes ambitioner på arbetet genom att hänföra det till att" det är så män är”. Män hävdar att de vet sanningen, men inte i kraft av att besitta kunskap utan bara genom vilka de är. I nästa mening utmanar hon fördomarna med fakta: fotot av henne och lastbilen. Genusregimen på fabriken i Durban var emellertid mer fientlig mot kvinnor som ville utvecklas i sitt arbete än vad den var på bussfabriken i Mexiko. I den senare arbetade flera kvinnor direkt $\mathrm{i}$ produktionen, även om det fanns ett visst motstånd från männen, men i Durban fick endast ett fåtal göra det: 
Nej, du är kvinna, sa de ... Men säg inte till mig att jag inte kan, för det kan jag. Här på fabriken säger de att jag inte kan göra det för att det är för tungt. Vid bandet säger jag till killarna: ”Låt mig försöka, och om jag misslyckas säger jag till. Vänta och se. Jag gör det igen, jag gör det bättre. Jag kan göra det.” (Emana)

De flesta manliga arbetare i Durban hävdade i intervjuerna att arbetet vid bandet var "för tungt" för kvinnor. Det var ett argument som syftade till att förmedla en speciell omtanke om de kvinnliga arbetarna. Men det fanns en uppenbar motsättning mellan hur männen beskrev kvinnornas arbete i fabriken - som endast mindre arbetsuppgifter - och hur kvinnorna beskrev att de utförde samma jobb som männen. I Mexiko liksom i Durban utmanade kvinnorna genusregimer som stängde dem ute från manligt kodade arbetsuppgifter och moment. I detta var kvinnorna mer framgångsrika i Mexiko, delvis på grund av ledningens strategi, vilken gick ut på att utnyttja kvinnors entusiasm för sina nyvunna positioner för att spela ut dem mot deras manliga kollegor.

\section{Sverige: Jämställdhet som könssegregering - kvinnor $i$ industrin och flykten från vården}

Sverige beskrivs ofta som ett pionjärland för jämställdhet. Uppbyggnaden av välfärdsstaten har syftat till att göra det möjligt att kombinera familjeliv med betald anställning. Trots detta och trots kvinnors långvariga närvaro på svensk arbetsmarknad (Askegård 2002) är glastaket intakt och kvinnor är överrepresenterade inom vissa sektorer med låga löner, som vård och offentlig sektor. Dessutom, trots många viktiga förändringar, fortsätter kvinnor att ha huvudansvaret för hushållsarbetet (Lundqvist 2011; Martinsson m.fl. 2016).

I kontrast till kvinnorna i Mexiko, som förklarade sin närvaro i industrin med att de till varje pris behövde ett jobb och att de var mer kvalificerade för jobbet än männen, gav oss kvinnorna i Sverige förklaringar som hade att göra med varför de inte arbetade inom vården. Vi tolkar det som ett resultat av ett nationellt sammanhang där kvinnlighet, särskilt arbetarklassens kvinnlighet, historiskt har kopplats till vårdyrkena. I våra intervjuer på Volvo i Umeå jämförde de kvinnliga 
arbetstagarna sina anställningar inom industrin med de traditionella sysselsättningsmönstren inom omsorgs- och vårdyrkena (Selberg 2012; andra studier om Volvo och dess anställda är t.ex. Ohlsson 2008 och Wallace 2004). Carina berättar:

Jag var utbildad som svetsare men jag tog jobb inom vården eftersom det inte fanns några jobb som svetsare på landsbygden. Och när jag hade jobbat som personlig assistent under nästan ett år kände jag att "Nej, om jag inte kommer in på akutsjukvården så gör jag något annat." Och då var det en kompis som sa: "Men du är ju svetsare. De behöver svetsare på Volvo. Sök. Du är kvinna. Du kommer att få jobbet." Så jag sökte och fick jobbet. (Carina)

Genus som ett system för social organisation framträder på olika nivåer i detta citat. Carina blev svetsare, ett arbete som kodas som manligt, men hennes första jobb var som personlig assistent inom vården, ett arbete som kodas som kvinnligt och tillgängligt för personer utan högre kvalifikationer. Det är kanske inte överraskande att Carina ville lämna det jobbet, men däremot att hennes första steg var att söka sig till ett mer utmanande jobb inom vården, i stället för att återgå till sitt ursprungliga kompetensområde som svetsare. I det läget var det Volvos rekryteringspolitik som gjorde det möjligt för henne att byta från ett "kvinnojobb" till ett "mansjobb", just för att hon var kvinna. Volvo ville anställa kvinnliga svetsare för att uppfylla kraven på jämställdhet.

I den vardagliga arbetsprocessen verkar jämställdhet inte betyda att ha samma rättigheter samtidigt som man kan vara olika. Snarare tycks det finnas en press på att bli lika, med mannen som måttstock för hur kvinnor bör vara:

Ja, jag fick en skada. Min handled måste opereras. Det var ett stort stycke i betong. Så jag protesterade och sa att "Det där är för tungt för killarna också." Och han som stod där sa bara att "Nej, det där är ingenting." Men om det är för tungt för oss så tar det bara lite längre tid för killarna att slitas ut. Jag tror det var det som hände. Två av dem skadade axeln och var tvungna att sjukskriva sig. Det tog bara längre 
tid. Men för mig gick det ganska fort. Vi är svagare, så är det bara. Vi slits ut snabbare. (Barbro)

Att acceptera sina svårigheter innebär för Barbro att erkänna att män och kvinnor är olika när det gäller fysisk förmåga. Men hon kunde göra det till en fördel i och med att kvinnors kroppar kan fungera som en sorts seismografer som känner av fara tidigare, ett argument som hon kan använda för att kräva arbetsförhållanden som också skyddar mäns kroppar. Fackföreningsrepresentanten Ana uppmuntrar det perspektivet:

Vi måste hela tiden kämpa för arbetsförhållanden som är anpassade för alla. Man ska helt enkelt inte behöva slita ut sig. Och det är där regler om lika möjligheter kommer in, att kvinnor och män ska behandlas lika. Både män och kvinnor har problem. Det är inte tänkt att du ska vara en alfa-person, helt frisk, hundra procent, för att du ska kunna göra jobbet utan att få problem med axlar, ryggen, fötterna. Du måste kunna göra ditt jobb även när du inte är hundra procent frisk. (Ana)

Att tränas i omsorg under hela livet och i många fall ha erfarenheter från vården kan bli en tillgång för kvinnor på manligt dominerade arbetsplatser. Även om jämställdhet kan sägas definiera genusordningen i det svenska samhället talar det faktum att kvinnor är överrepresenterade inom vårdsektorn ett annat språk. Samma språk präglar genusregimen i Volvofabriken. Även om Carina var anställd som svetsare fanns en arbetsdelning i fabriken där kvinnor i produktionen främst arbetade i måleriet och var underrepresenterade i sektioner med "tunga jobb":

Det har varit få kvinnor och på svetsstationen var först vi fem, sedan var vi tjugo och nu är vi tretton av 350 . Så vi är väldigt få. Alla kvinnor som har varit här har stannat endast en kort period och sedan lämnat. Men vi är fyra som har kunnat hålla oss kvar. (Kristina)

Kristinas förklaring till att kvinnor lämnar branschen skiftar mellan biologiska förklaringar (kvinnors fysiska konstitution) och psykologiska (den tuffa miljön). 
Det är tungt. Det är tungt att jobba som svetsare. Inte att hålla i och dra en svets, det är inte tungt. Men allting runtomkring. Arbetet, lyften, att stå i svåra fysiska positioner, att jobba med punktsvetsning. [...] Även om du är stark som tjej är du fortfarande svagare. Det finns killar som inte kan lyfta ett papper, men de är få. Om man jämför kvinnor som grupp med män som grupp är vi svagare, hur stark du än är. Sen är det saker som att vissa unga tjejer hamnar i grupper där det kan vara psykiskt tufft att vara. (Kristina)

Å ena sidan tycks Kristina bekräfta den bedömning som de sydafrikanska manliga arbetarna gjorde, att kvinnor är för svaga för att arbeta i produktionen. Å andra sidan konstruerar hon en liknande självständig subjektivitet som industriarbetare som vi kunde se i både Mexiko och Sydafrika när hon beskriver hur tufft arbetet som svetsare är och säger att hon är en av få kvinnor som kunnat hålla sig kvar i yrket.

\section{Avslutande reflektioner}

Vår studie av kvinnors närvaro i ett transnationellt företag öppnar för olika tolkningar av deras erfarenheter. På ett övergripande plan kunde vi se en sorts allians mellan det transnationella företaget och kvinnornas intressen, när företaget bedrev en aktiv jämställdhetspolitik eller när de anställde kvinnor för att underminera manliga arbetares högre krav. I de tre fabrikerna reglerades kvinnornas integration av olika genusregimer: $\mathrm{i}$ Mexiko förkroppsligade kvinnorna förändringar i arbetsorganisationen i ett sammanhang där nyliberala satsningar utlovade fördelar för dem. I Sydafrika anställdes kvinnorna, och unga män, som alternativ till fackligt organiserade och erfarna manliga arbetare. I Sverige uttryckte kvinnorna tveksamhet angående sin identifikation som industriarbetare. Vid samtliga tre anläggningar positionerades kvinnor på en och samma gång som hemarbetande och industriarbetare.

I Mexiko och Sydafrika inkluderade inte de manliga arbetarna kvinnorna i sina klassorganisationer eller i gemenskapen på fabriksgolvet, utan såg dem som ojusta konkurrenter. Om en kvinna blev stolt över att hon kunde göra ett arbete som två arbetare hade gjort tidigare kan man föreställa sig varför männen inte såg det som en framgång att 
kvinnor anställdes i fabriken. I stället för att inkludera kvinnorna och förhandla utifrån deras gemensamma intressen marginaliserade de dem och ifrågasatte deras lämplighet. Eftersom kvinnorna ville ha jobb och vidareutveckla sin kompetens kunde ledningen agera som deras supportrar och på så vis spela ut män och kvinnor mot varandra. I Sverige fungerade industriarbetet som en väg bort från omsorgsarbete både i och utanför hushållet. Samtidigt kunde arbete i vården vara en viktig källa till kvinnors identitet och till deras kunskaper och strategier för att införa förbättringar av arbetsmiljön på manligt dominerade arbetsplatser.

Man måste förstå kvinnors motsägelsefulla position i fabrikerna som på samma gång stolta arbetare och en marginaliserad grupp mot bakgrund av de socioekonomiska förhållandena i de tre länderna. Ålder och ras var centralt i Sydafrika, där unga svarta kvinnor och män kämpade för att bidra till försörjningen av stora hushåll och ansvara för hemarbetet. Mexikos stigande arbetslöshet och förändrade genusrelationer gjorde det möjligt för kvinnor, även gifta, att komma in på arbetsmarknaden, vilket gav dem vidgade yrkeserfarenheter men också innebar ytterligare bördor. I båda dessa länder baserades Volvos "modernitet" och "normalitet" paradoxalt nog på exproprieringen av de anställdas självförsörjningsresurser och informella ekonomier, det vill säga på "överexploatering" i marxistiska termer. Den tillfredsställelse över sitt arbete som de mexikanska och sydafrikanska arbetarna uttryckte stod i kontrast till den känsla av övermäktigt ansvar som försörjningsbördan innebar. Det här spänningsförhållandet blottlägger motsägelserna i de rådande kulturella normerna: å ena sidan det nyliberala konsumtionssamhällets krav på individualitet, självutveckling och att satsa på sin karriär; å andra sidan traditionella krav på att kvinnor inte bara ska ta huvudansvaret för sin närmaste familj utan i allmänhet känna sig ansvariga för andra.

De kulturella normernas motsägelsefulla krav kan knytas till allmänmänskliga önskningar, behov och förmågor att bry sig om andra och leva i samarbetsinriktade och solidariska samhällen. Att kapitalistiska produktionsformer har lyckats med att kolonisera människors önskan att göra gott och ta hand om andra är kanske den mest tragiska dimensionen av kapitalismens och nyliberalismens framgångshistoria. Inte bara utnyttjas mänskliga behov genom morot-och-piska-strategier 
där exempelvis kvinnliga arbetstagare får möjlighet att utveckla sina förmågor samtidigt som de hotas av arbetslöshet och fattigdom om de inte underordnar sig företagets önskemål. Kapitalet har också kunnat skilja behoven från varandra och därigenom omvandla dem från att vara konstruktiva till att bli destruktiva: lusten att skapa något användbart och göra ett bra jobb för den egna sakens skull avskiljs från förmågan att bry sig om andra arbetstagare och arbeta under jämställda villkor. Lusten blir en individualistisk privatiserad önskan om framgång på andras bekostnad och på så sätt blir den självdestruktiv. Kvinnorna i Mexiko som var stolta över att de kunde göra ett jobb som tidigare hade krävt två personer medverkade till att göra arbetare överflödiga, och förr eller senare kommer det att drabba dem själva. Önskan att ge omsorg blir avskuren från praktiken, och förmågan att göra någonting till nytta för andra förvandlas till en självuppoffrande praktik som kräver andras beroende och underordning.

De kvinnliga industriarbetare vi intervjuade delade kön och klass och många gemensamma erfarenheter. Men deras berättelser visar också viktiga skillnader i hur den ekonomiska globaliseringen har tagit sig uttryck i de nationella och lokala sammanhangen, vilket har skapat olika förutsättningar för kvinnors arbete, vardagsliv och subjektsformationer. I motsats till sina kollegor i det globala syd har Volvoarbetare i Sverige fortfarande privilegiet att få en lön som går att leva på, även om arbetsvillkoren har försämrats. Vår studie visar vidare att kategorierna "klass", "ras" och "kön" är nödvändiga men inte tillräckliga för att förstå möjligheterna och motsättningarna i de anställdas vardagsliv. Förutom i de historiska och rumsliga sammanhangen behövs insikter i de vardagliga praktiker på arbetsplatserna genom och inom vilka kvinnors subjektiviteter konstrueras.

Kvinnor som förvärvsarbetar och som under ett kapitalistiskt företags exploaterande styrning uttrycker tillfredsställelse över att göra ett gott jobb och vara produktiva, slits mellan möjligheten att utveckla ett nytt självförtroende och nödvändigheten att uppoffra sig i och med att de ansvarar för familjeförsörjningen. Under de skoningslösa nyliberala regimerna pågår den oändliga diskussionen om balans mellan arbete och liv, även formulerat som kvinnors dubbla eller tredubbla börda (Lewis 2009; Nilsen m.fl. 2017). Dessa abstrakta och till och med 
eufemistiska begrepp fångar inte kvinnors djupa splittring mellan två önskningar och två former av självförverkligande: önskan att bli skicklig på att producera någonting bra för dess egen skull, och den samtidiga önskan att ge omsorg till sina familjemedlemmar. Berättelserna om de samtidiga känslorna av tillfredsställelse och otillräcklighet visar att två halva liv inte kan summeras till ett helt liv som uppfyller mänskliga behov (Benería m.fl. 2016).

Vad säger vår studie om kapitalismens "normalitet"? Volvos olika ansikten i Sverige, Mexiko och Sydafrika visade att en "normalitet", en kapitalism "med mänskligt ansikte", som betalar rättvisa löner, tillåter anständiga arbetstider och gör det möjligt för de anställda att försörja barn och gamla, bara finns där arbetarna har tillräckligt med makt (Silver 2003). I Mexiko och Sydafrika fick vi höra fackliga röster om att Volvo och svenska företag i allmänhet var de värsta arbetsgivarna. Ett och samma företag agerade som en relativt rättvis arbetsgivare i det globala nord och som en överexploaterande arbetsgivare i det globala syd. Det speglar ett känt kolonialt mönster av paternalism mot egna medborgare och överutnyttjande och underordnande av andra. Samhällsstrukturerna tvingade företaget att vara rättvist i nord, medan andra samhällsstrukturer tillät det att vara överexploaterande i syd. Det enda sättet att övervinna detta vore gemensam kamp bland anställda i det globala syd och det globala nord för att stärka positionerna för arbetstagarna, män och kvinnor, och skapa globalt rättvisa spelregler. ${ }^{1}$

\section{Noter}

1 Det här kapitlet är ett omarbetat utdrag från några av de resultat vi publicerat i vår bok Transnational corporations from the standpoint of workers (Räthzel, Mulinari \& Tollefsen 2014). Projektet finansierades av VR (Vetenskapsrådet) https://www. umu.se/en/research/projects/globalisation-and-everyday-working-life/.

\section{Referenser}

Arciniega, R.S. (2012) "Participación de Mujeres en el Mercado Laboral del Estado de México", Journal of Latin American Geography 11(1):121-141. https://doi. org/10.1353/lag.2012.0022.

Askegård, J. (red.) (2002). Kvinnor tar plats: arbetsmarknad och industriarbete på 19oo-talet. Stockholm: Arbetarrörelsens arkiv och bibliotek. 
Benería, L. (1992) "Accounting for women's work: the progress of two decades", World Development. 20(11):1547-1560. https://doi.org/10.1016/0305-750X(92)90013-L.

Benería, L. (2008). "The crisis of care, international migration, and public policy", Feminist Economics 14(3):1-21.

Benería, L., Berik, G. \& Floro, M. (2016) Gender, development, and globalization: economics as if all people mattered. New York \& London: Routledge, Taylor \& Francis.

Berger, I. (1992) Threads of solidarity: women in South African industry, 1900-1980. Bloomington \& Indianapolis: Indiana University Press.

Berggren, C. (1992) The Volvo experience: Alternatives to lean production in the Swedish auto industry. London: Macmillan.

Brenner, J. (2000) Women and the politics of class. New York: Monthly Review.

Burawoy, M. (1998) "The extended case method", Sociological Theory 16(1):4-33. https://doi.org/10.1111/0735-2751.00040.

Chant, S. (2014) "Exploring the 'feminisation of poverty' in relation to women's work and home-based enterprise in slums of the Global South", International Journal of Gender and Entrepreneurship, 6(3):296-305.

Connell, R. (1990) "The state, gender, and sexual politics: Theory and appraisal", Theory and Society 19(5):507-544.

Connell, R.W. (2002) Om genus. Göteborg: Bokförlaget Daidalos.

Connell, R. (2005) "Advancing gender reform in large-scale organisations: A new approach for practitioners and researchers", Policy and Society 24(4):5-24. https://doi.org/10.1016/S1449-4035(05)70066-7.

Cortés, F. (2000) La evolución de la Desigualdad del Ingreso Familiar durante la decada de los Ochenta. Ciudad de México: Centro de Estudios Sociológicos, El Colegio de Méjico.

Darkwah, A. (2007) "Making hay while the sun shines: Ghanaian female traders and their insertion in the global economy". I N. Gunewardena \& A.E. Kingsolver (red.) The gender of globalization: Women navigating cultural and economic marginalities. Santa Fe, NM: School for Advanced Research Press.

de la Garza Toledo, E. (2006) (red.). Teorías sociales y estudios del trabajo. Nuevos enfoques. Anthropos. Mejico, D:F: Universidad Autónoma Metropolitana.

de la Rocha, G. (2001) "From the resources of poverty to the poverty of resources?: The erosion of a survival model", Latin American Perspectives 28(4):72-100. https://doi.org/10.1177/0094582X0102800405.

de la Rocha, M.G. (2015) "From the resources of poverty to the poverty of resources: The erosion of a survival model". I S. Chant \& G. Beetham (red.) Gender, poverty, and development, critical concepts in development studies. London: Routledge.

Enloe, C.H. (2004) The curious feminist: searching for women in a new age of empire. Berkeley: University of California Press.

Eraydin, A. \& Erendil, A. (1999) "The role of female labour in industrial restructuring: New production processes and labour market relations in the Istanbul clothing industry", Gender, Place \& Culture. 6(3):259-272. https://doi. org/10.1080/09663699925024.

Farris, S. \& Rottenberg, C. (2017) "Introduction: Righting feminism”, New Formations 91:5-15.

Federici, S.B. (2014) Caliban and the witch. New York: Autonomedia. 
Ferguson, S. (2016) "Intersectionality and social-reproduction feminisms: Toward an integrative ontology", Historical Materialism 24(2):38-6o. https://doi. org/10.1163/1569206X-12341471.

Fernandez Kelly, M-P. (1984) For we are sold, I and my people: Women and industry in Mexico's frontier. New York: SUNY Series in the Anthropology of Work.

Ferrant, G., Pesando, L.M. \& Nowacka, K. (2014) Unpaid care work. The missing link in the analysis of gender gaps in labour outcomes. OECD Development Centre. https://www.oecd.org/dev/development-gender/Unpaid_care_work. pdf, hämtad december 2018.

Funari V. \& de la Torre, S. (2006) Maquilapolis. City of factories. http://www. maquilapolis.com/project_esp.htm.

Gibson, D. \& Rosenkrantz Lindegaard, M. (2003) "South African boys with plans for the future: Why a focus on dominant discourses tells us only part of the story”. I T. Schefer, K. Ratele, N. Strebel, N. Shabala \& R. Nuikema (red.) From boys to men: Social constructions of masculinity in contemporary society. Capetown: University of Capetown.

Gibson-Graham, J.K. (2006) The end of capitalism (as we knew it): a feminist critique of political economy. Minneapolis: University of Minnesota Press.

Glenn, E.N. (1992) "From servitude to service work: Historical continuities in the racial division of paid reproductive labor", Signs: Journal of Women in Culture and Society 18(1):1-43. https://doi.org/10.1086/494777.

Grabham, E., Cooper, D., Krishnadas, J. \& Herman, D. (red.) (2009) Intersectionality and beyond: law, power and the politics of location. Abingdon: Routledge-Cavendish.

Gramsci, A. (1971) Prison notebooks. New York: International Publishers.

Gutierrez Arriola, A. (2006) La empresa transnacional en la reestructuración del capital, la producción y el trabajo. México: Casa Juan Pablos.

Gutmann, M. (1996) The meanings of macho: Being a man in Mexico City. Berkeley: University of California Press.

Hall, S. (1996) "Who needs 'identity'?". I S. Hall \& P. du Gay (red.) Questions of cultural identity. Subject, self and idenity in cultural studies. London: Sage.

Hennessy, R. (200o) Profit and pleasure: sexual identities in late capitalism. New York: Routledge.

ILO (2018) International Labour Office. World employment social outlook. Trends for women. https://www.ilo.org/wcmsp5/groups/public/---dgreports/---dcomm/---publ/documents/publication/wcms_619577.pdf.

Lagarde de los Ríos, M. (2011) Los cautiverios de las mujeres: madresposas, monjas, putas, presas y locas. Madrid: Horas y Horas.

Lapati, A. \& de la Rocha, M. (2009) "Girls, mothers and poverty reduction in Mexico". I S. Razavi (red.). The gender impact of liberalisation. Towards "embedded liberalism"?. New York: Routledge.

Lewis, J. (2009) Work-family balance, gender and policy. Northampton: Edward Elgar Publishing.

Lundqvist, Å. (2011) Family policy paradoxes: Gender equality and labour market regulation in Sweden, 1930-2010. Bristol: Bristol University Press. https://doi. org/10.2307/j.ctt9qgqx7. 
Martinsson, L., Griffin, G. \& Giritli Nygren, K. (red.) (2016) Challenging the myth of gender equality in Sweden. Bristol, Il: Policy Press.

Marx, K. (1998) Kapitalet. Första boken. Kapitalets produktionsprocess. Förord till första upplagan. https://www.marxists.org/svenska/marx/1867/23-d10o.htm.

Massey, D. (1994) Space, place and gender. Cambridge: Polity Press.

Massey, D.B. (2005) For space. Thousand Oaks \& London: SAGE.

McNay, L. (2000) Gender and agency: reconfiguring the subject in feminist and social theory. Cambridge, UK: Polity Press.

McRobbie, A. (2009) The aftermath offeminism: gender, culture and social change. Los Angeles \& London: Sage.

Mohanty, C.T. (1997) "Women workers and capitalist scripts: Ideologies of domination, common interests and the politics of solidarity". I M.J. Alexander \& C.T. Mohanty (red.) Feminist genealogies, colonial legacies, democratic futures. New York: Routledge.

Mohanty, C.T. (2003) Feminism without borders: decolonizing theory, practicing solidarity. Durham \& London: Duke University Press.

Mosoetsa, S. (2005) Micro-level responses to macro-economic changes: Urban livehoods and intra-household dynamics in South Africa. Diss. Johannesburg, S.A: Faculty of Humanities, University of Witwatersrand.

Mulinari, D. \& Räthzel, N. (2009) 'The promise of the 'Nordic' and its reality in the south: The experiences of mexican workers as members of the 'Volvo family". I S. Keskinen, S. Tuori, S. Irni \& D. Mulinari (red.) Complying with colonialism. Farnham, England; Burlington: Aldershot:Ashgate.

Mulinari, D., Räthzel, N. \& Tollefsen, A. (2011). "Everyday working lives in a transnational corporation in Mexico: the contradictory co-optation of trade unionists". Economic and Industrial Democracy 32(3):379-399. https://doi. org/10.1177/0143831X10377811.

Nagar, R., Lawson, V., McDowell, L. \& Hanson, S. (2002) "Locating globalization: Feminist (re)readings of the subjects and spaces of globalization", Economic Geography 78(3):257-284.

Nilsen, W., Skipstein, A., Østby, K.A. \& Mykletun, A. (2017) "Examination of the double burden hypothesis - a systematic review of work-family conflict and sickness absence", European Journal of Public Health 27(3):465-471. https://doi. org/10.1093/eurpub/ckxo54.

Nnaemeka, O. (1998) "This women's studies business: Beyond politics and history (Thoughts on the first WAAD conference)". I O. Nnaemeka (red.) Sisterhood, Feminisms and Power. Trenton, NJ: Africa World Press.

Ohlsson, B. (2008) Vi som stannade på Volvo: en etnologisk studie om äldre bilindustriarbetares arbetsliv och framtidsplaner. Göteborg: Arkipelag.

Ong, A. (2006) Neoliberalism as exception: mutations in citizenship and sovereignty. Durham NC: Duke University Press.

Räthzel, N., Mulinari, D., Tollefsen, A., Molina, I. \& Mählck, P. (2008) ”Unvollendete Transformationen: Widerstreitende Zugehörigkeiten, aufbrechende Geschlechterverhältnisse, Stadt-Land-Beziehungen. Arbeitsalltag in einem europäischen transnationalen Unternehmen in Mexiko", Forum Kritische Psychologie 52:29-51. 
Räthzel, N., Mulinari, D. \& Tollefsen, A. (2014) Transnational corporations from the standpoint of workers. Basingstoke: Palgrave Macmillan.

Salzinger, L. (2003) Genders in production: making workers in Mexico's global factories. Berkeley: University of California Press.

Selberg, R. (2012) Femininity at work: gender, labour, and changing relations of power in a Swedish hospital. Lund: Arkiv.

Silver, B. (2003) Workers' movements and globalization since 1870: Forces of labour. Cambridge: Cambridge University Press.

Smith, D. (2005) "Institutional ethnography". I T. May (red.) Qualitative research in action: An international guide to issues in practice. London: Sage.

Solis de Alba, A.A. (1990) "Las trabajadoras y el movimiento obrero en México, 1982-1988", Revista Iztapalapa 19:125-142.

SOU. Statens offentliga utredningar (2004) Den könsuppdelade arbetsmarknaden. 2004:43. https://www.regeringen.se/49bb92/contentassets/b46b81ff8ea142fcb535f7od3919d696/makt-att-forma-samhallet-och-sitt-eget-liv-kapitel-6-9-del2-av-4-sou-200566. Hämtad december 2018.

Standing, G. (1989) "Global feminization through flexible labor", World Development 17(7): 1077-1095. https://doi.org/10.1016/0305-750X(89)90170-8.

Statistics South Africa (2018). How do women fare in the South African labour market. http://www.statssa.gov.za/?p=11375. Publicerad 1 augusti 2018, hämtad i december 2018).

Szasz I. \& Amuchástegui A. (2007) Sucede que me canso de ser hombre... Relatos $y$ reflexiones sobre hombres y masculinidades en México. México: El Colegio de México.

Tornhill, S. (2011) "Capital visions: Scripting progress and work in Nicaraguan free-trade zones", Latin American Perspectives 38(5):74-92.

Tshoaedi, M. (2012) "Women in the forefront of workplace struggles in South Africa: From invisibility to mobilization", Labour, Capital and Society 45(2):58-83.

Vanguardia (2017). "Solo el $17 \%$ de las mujeres trabajan en la industria." https:// vanguardia.com.mx/articulo, hämtad december 2018.

Wallace, T. (2004) "Innovation and hybridization: Managing the introduction of lean production into Volvo do Brazil", International Journal of Operations \& Production Management 24(8): 801-819. https://doi.org/10.1108/01443570410548239.

Wallace, T. (2007) "Is that something we used to do in the 1970s? The demise of 'good work' in the Volvo corporation". I S. Bolton (red.) Dimensions of Dignity at Work. London: Elsevier. 